\title{
US senators urge caution on cloning ban
}

[WASHINGTON] Several influential US congressmen last week urged their colleagues to take a calmer approach to human cloning, after an initial burst of support for restrictive legislation that followed last month's announcement that a sheep had been cloned.

But at the end of the week, the 18-member National Bioethics Advisory Commission (NBAC), which has been asked by President Bill Clinton to draw up policy recommendations on human cloning, heard a wide range of views, from calls to treat human cloning as simply another form of assisted reproductive technology to "grave concerns" from animal rights activists about cloning's implications for animal welfare.

Separately, in California, State Senator Patrick Johnston introduced a bill banning human cloning research and experiments for five years. But the office of Republican governor Pete Wilson's cautioned against a "knee-jerk action" that could threaten valuable research.

Among the national politicians urging caution about legislation was John Porter (Republican, Illinois), chair of the subcommittee in the House of Representatives that funds the National Institutes of Health (NIH). Porter said that "cloning itself can lead to a great deal of progress in science", and added: "I think we should simply take a good, hard, long look at it."

Such sentiments were echoed by Connie Mack (Republican, Florida), a key Senate supporter of biomedical research, and Senator Bill Frist (Republican, Tennessee), the heart surgeon who heads the public health and safety subcommittee of the Senate Labor

and Human Resources Committee.

Frist compared the current uproar to the public reaction to the first heart transplants. He said that he opposed any legislation that would block the potential benefits of human cloning research for diseases such as cystic fibrosis and sickle-cell anaemia.

Since the news of the sheep cloning was reported, Clinton has banned federal funding for "cloning of human beings". Two bills have been introduced in Congress that would ban federal funding for human cloning, and another would impose a $\$ 5,000$ civil penalty on anyone doing such work (see Nature 386, 97; 1997).

Appearing before Frist's subcommittee last week, Ian Wilmut, who led the team of scientists who cloned the sheep at the Roslin Institute in Edinburgh, endorsed proposals for an international ban on human cloning, and said he took comfort in existing British legislation on this issue.

While urging senators not to "throw out this baby with the bath water" by enacting legislation that would impose excessive restrictions on research, he pointed out that "many of the most important experiments could more readily be carried out" with laboratory or farm animals.

As for cloning humans for reproductive purposes, Wilmut said he had never heard of a reason for this that he found ethically acceptable. When Tom Harkin (Democrat, Iowa) called such caution "utter nonsense" and predicted human cloning in his lifetime, Wilmut said: "I hope you're wrong."

At the same hearing, Harold Varmus, the NIH director, urged the senators not to legislate. He credited the existence of a "vibrant"

\section{WHO chief defends use of animal models}

[GENEVA] Hiroshi Nakajima,

director-general of the World

Health Organization (MHO),

warned last week that

opposition to human cloning

should not lead to an

indiscriminate ban on all

cloning procedures and

research, and praised the

potential benefits of animal

cloning to human health.

In a statement released

by $\mathrm{WHO}$ headquarters in

Geneva, Switzerland,

Nakajima condemned the

use of cloning to replicate

humans as "ethically

unacceptable", as it would

violate some of the basic

principles governing

medically assisted

\section{procreation.}

But he pointed out that the cloning of human cell lines is a routine procedure in the production of monoclonal antibodies for diagnosis and research on diseases such as cancer. "Animal cloning also offers opportunities to advance research on diagnosis and treatment of diseases affecting human beings," Nakajima said.

The implications of the recent experiments at the Roslin Institute in Scotland will be discussed next month at a meeting of the scientific and ethical review group of the WHO's special programme on research, development and research training in human reproduction.

Meanwhile, Edith Cresson the European Commissioner responsible for research, told the European Parliament last week that there should be a total ban on cloning human beings - a proposal that was unanimously endorsed by the parliament. But Cresson said that there should be common agreement in Europe on human cloning, where opinions already differred widely, before attempts were made to establish a global agreement.

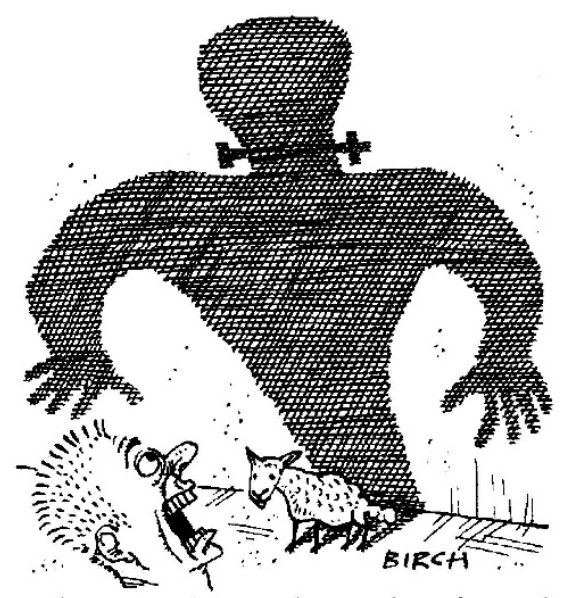

US biotechnology industry directly to the lack of legislation on recombinant DNA technology when it first emerged. "When I hear about research on human cloning as something that ought to be taken away, I shiver," said Varmus.

But Christopher Bond (Republican, Missouri), who last month introduced a bill banning federal funding for research related to the cloning of humans, told the hearing that this topic did not need to be studied. "There are aspects of human life that should be off limits to science," he said.

Separately, the NBAC heard two days of testimony from religious figures, ethicists, scientists and the public. Leon Kass, a professor of social thought at the University of Chicago, told the commission that human cloning is "radically new" and dangerous.

Kass said that human cloning would be impossible without unethical experiments, and presents an unacceptable threat to human identity and individuality. As a technique for turning "procreation into manufacture", he argued that cloning represents an attempted human control of progeny that is "inherently despotic".

But two ethicists disagreed. John Robertson, a professor at the University of Texas at Austin, argued that a ban on cloning would unacceptably infringe scientific and reproductive freedoms which he said are protected by the US constitution.

He said that cloning was "much less ominous" than the manipulation of human genomes, as it simply duplicates an existing genome. In the absence of demonstrable harm to others, cloning should receive the same protection as other non-coital methods of assisted reproduction, he argued.

Ruth Macklin, a bioethicist at Albert Einstein College of Medicine in New York, said that it will be crucial to distinguish between cellular level cloning for research purposes and cloning with the aim of producing a human being. She urged the government to develop a regulatory framework to control human cloning research. 